\title{
Evaluation of Knowledge Transfer in E-Learning Version 3.5 of The Pamulang University With COLLES Method
}

\author{
Thoyyibah. $\mathrm{T}^{1}$, Wasis Haryono ${ }^{2}$ \\ \{dosen01116@unpam.ac.id ${ }^{1}$, Wasish@unpam.ac.id² \\ Affiliation Information Technology Department, University of Pamulang ${ }^{1}$
}

\begin{abstract}
The teaching and learning process is basically a process where knowledge is transferred from teacher to student. All processes in the Knowledge that are supported by an application are called Knowledge Management System (KMS). Especially in the world of education, KMS is closely related to e-learning or online learning systems. The problem that is often faced in implementing e-learning in an institution is how to make users of the e-learning system feel comfortable, especially in order to support an effective knowledge sharing process. The purpose of this study is to know the level of comfort of students in using E-learning version 3.5 and the extent to which students use E-learning version 3.5 of the pamulang university in the Knowledge Sharing process. The method in this study, which is COLLES or Constructivist On-Line Learning Environment Survey, is a questionnaire specifically aimed at knowing the level of comfort in using the E-learning system. This method consists of 6 categories namely Relevance, Reflection, Interactivity, Tutor Support, Peer Support, Interpretation. The results of this study are that students have understood the use of e-learning. This is seen from the results of the suitability of the elearning system to student knowledge levels. Based on the COLLES method, the process of knowledge sharing in e-learning 3.5 UNPAM has gone well.
\end{abstract}

Keywords: COLLES, E-Learning, Pamulang University

\section{Introduction}

Web-based learning has been used frequently [1]. Various ways are used to restructure the education system with many technologies [2]. The use of a digital environment supports communication and independence while respecting differences of opinion [3]. The world of education is one of the fields related to knowledge. Knowledge becomes effective because of the transfer of knowledge supported by the application and is called the KMS (Knowledge Management System). KMS in the learning process is closely related to E-learning. E-learning is the function of the transformation of knowledge to increase learning motivation [4]. Technology plays an important role in various circles, not only in schools but in many educational institutions [5].

E-Learning can be accessed anytime and anywhere [6]. E-learning can also improve student competence [7]. Besides that, E-learning is able to manage classes without having to meet in person [3] E-Learning is an education organization that does not consider the time and range for students who cannot enter the class [8]. Continuous learning process designed to improve quality and collaboration between lecturers and students [9]. With E-learning a lot of learning 
is diverted online [10]. In order to interact online more efficiently the comfort factor needs to be considered [11]. This is subjective so that measuring instruments with the COLLES method are very helpful. This method consists of relevance, reflective thinking, interactivity, tutor support, peer support, interpretation. This method is in the form of a questionnaire with 24 questions to determine the level of convenience of using the learning system. This research was applied to e-learning 3.5 of the University of Pamulang in informatics engineering with 10 respondents.

\section{Knowledge}

Knowledge is the clarity of data and information into the context of information technology so that knowledge is stored in digital form [12][12]. Knowledge consists of two types, namely tacit knowledge and explicit knowledge. Tacit knowledge is an insight and experience in individuals who are not known that they use it actively or knowledge in the form of experiences that exist in each individual [13]. Whereas explicit knowledge is knowledge that can rationally be expressed in words, sentences, numbers or formulas as outlined in the form of books, documents, journals, etc. [14] Besides, knowledge management is a field of study that can improve sharing processes, distribution , creating, capturing, and understanding knowledge so that knowledge is not in vain [15]. Knowledge management consists of software systems and integrates and disseminates information to users for the learning process and making decisions [16]. Knowledge management systems are the integration of technology and mechanisms developed to support the knowledge management process [17].

\section{E-Learning}

E-learning is a new educational paradigm in the age of information technology [18]. E-Learning is a long-term learning objective with different individual psychological characteristics [19]. ELearning means education where instructions and content are delivered via the internet [20]. ELearning or electronic learning is a process that utilizes information technology in this case using online media such as the internet as a method of delivery, interaction and facilitation. ELearning is the process of transferring knowledge through computer media, computer networks and the internet. Types of e-learning applications in the form of the web, virtual education and all digital content in the forms of images, videos and animations [21]. The learning process in e-learning has the advantages of not being bound by time and place so that it is usually done remotely [22]. Academic officials consider E-learning as long-term online learning [23]. Elearning allows learning and organizing a class without having to meet face to face. With the online education management system, students will evaluate themselves to be more competitive with other students [24]. E-Learning also provides facilities for teachers and students or lecturers and students to interact with each other in a learning environment through online social networking [25]. The use of E-Learning is expected to be able to improve the quality of learning, responsibility, quality of activities and independence of students [26]. Figure 1 is the main page in the online learning process at Pamulang University. Figure 1 also displays several courses that are taught by certain lecturers. As per picture 1 for example lecturer A teaches Indonesian 
language courses in classes 02TPLM016 and 02TPLM015, teaches language theory and automata in classes 06TPLE014 and 06TPLE015.

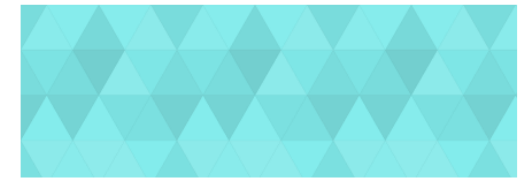

[2] BAHASA INDONESIA \# 02TPLM016 (Senin) $[M-1]$

$$
20182
$$

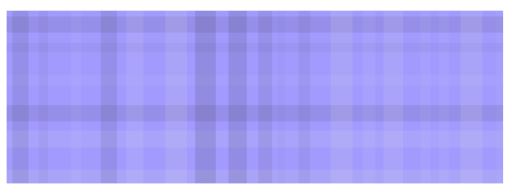

[2] TEORI BAHASA \& AUTOMATA \# 06TPLE015 (Sabtu) [E-1]

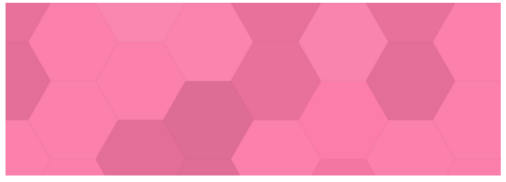

2] BAHASA INDONESIA \# 02TPLM015 (Senin) [M-1]

20182

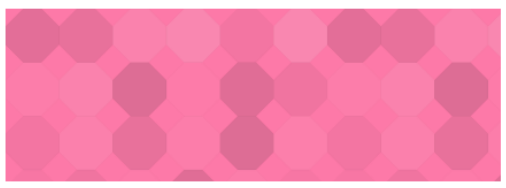

[2] TEORI BAHASA \& AUTOMATA \# D6TPLE014 (Sabtu) [E-1]

Figure.1 Main Page of E-learning University Pamulang

\section{COLLES METHOD}

\section{A. COLLES}

Contructivistic on-line learning Envi-rontment Survey (COLLES) developed by Peter Charles Taylor and Dorit Maor fromCurtin University of technology Australia in order to measure how many Web-based learning can enrich student knowledge through knowledge sharing [27]. According to COLLES has 3 types survey, namely:

1. The preferred form is print on opinion ideal students have inside online learning.

2. The actual form is highlighted at actual / real experience experienced students in online learning.

3. The preferred combination and the actual shape that is structural order for all student information both ideal and actual Elearning surfaces can be collected.

COLLES consists of 24 questions, which are divided into 6 (six) categories, where each category will describe the quality of using an online learning system [28]. 


\section{Relevance}

How relevant (suitability) is the e-learning system to the user's knowledge level?

2. Reflection

Does the e-learning system stimulate students to think critically and openly?

3. Interactivity

To what extent can students participate (interact) in the process of exchanging knowledge through e-learning systems?

4. Support Tutor

How far does the teacher give students the opportunity to participate in the e-learning system?

5. Peer Support

What is the support between fellow students in the e-learning system?

6. Interpretation

Do students and instructors have the same understanding in communicating online?

In this study the authors used 24 question for actual and 24 question for prefered. Assessment in COLLES uses a Likert scale which is divided into 5 (five) scales, namely strongly agree (5) or SS, agree (4) or S, neutral (3) or N, disagree (2) or TS, strongly disagree (1) or STS [23]. To calculate the results of the questionnaire, a COLLES assessment criterion was used, as follows[29]:
a) -1.79 Very Bad (VB)
b) $1,80-2,59 \mathrm{Bad}(\mathrm{B})$
c) 2,60-3,39 Fairly Good (FG)
d) $3,40-4,19$ Good (G)
e) 4,20-5,00 very Good (VG)

Table 1. COLLES method evaluation for actual

\begin{tabular}{llllllllll}
\hline No & Q & SS & S & N & TS & STS & Score & average & inf \\
\hline 1 & A & 3 & 6 & 1 & 0 & 0 & 42 & 4.2 & VG \\
& B & 3 & 5 & 2 & 0 & 0 & 41 & 4.1 & G \\
& C & 4 & 5 & 1 & 0 & 0 & 43 & 4.3 & VG \\
& D & 1 & 5 & 4 & 0 & 0 & 37 & 3.7 & G \\
2 & A & 3 & 6 & 1 & 0 & 0 & 42 & 4.2 & VG \\
& B & 2 & 7 & 1 & 0 & 0 & 41 & 4.1 & G \\
& C & 1 & 7 & 1 & 0 & 1 & 37 & 3.7 & G \\
& D & 1 & 7 & 1 & 0 & 1 & 37 & 3.7 & G \\
3 & A & 1 & 8 & 1 & 0 & 0 & 40 & 4.0 & G \\
& B & 0 & 7 & 3 & 0 & 0 & 37 & 3.7 & G \\
& C & 2 & 8 & 0 & 0 & 0 & 42 & 4.2 & VG \\
& D & 0 & 10 & 0 & 0 & 0 & 40 & 4.0 & G \\
4 & A & 1 & 8 & 1 & 0 & 0 & 40 & 4.0 & G \\
& B & 2 & 6 & 2 & 0 & 0 & 40 & 4.0 & G \\
& C & 3 & 6 & 1 & 0 & 0 & 42 & 4.2 & VG \\
& D & 1 & 8 & 1 & 0 & 0 & 40 & 4.0 & G \\
5 & A & 1 & 7 & 2 & 0 & 0 & 39 & 3.9 & G \\
& B & 2 & 5 & 3 & 0 & 0 & 39 & 3.9 & G \\
& C & 1 & 6 & 3 & 0 & 0 & 38 & 3.8 & G
\end{tabular}




\begin{tabular}{llllllllll} 
& $\mathrm{D}$ & 1 & 7 & 2 & 0 & 0 & 39 & 3.9 & $\mathrm{G}$ \\
6 & $\mathrm{~A}$ & 2 & 5 & 1 & 2 & 0 & 37 & 3.7 & $\mathrm{G}$ \\
& $\mathrm{B}$ & 0 & 8 & 1 & 1 & 0 & 37 & 3.7 & $\mathrm{G}$ \\
& $\mathrm{C}$ & 2 & 6 & 1 & 1 & 0 & 39 & 3.9 & $\mathrm{G}$ \\
& $\mathrm{D}$ & 1 & 9 & 0 & 0 & 0 & 42 & 4.2 & VG \\
\hline
\end{tabular}

The table consists of 6 sequences, 1,2,3,4,5,6. the sequence is 6 categories that are used for several questions, namely 1 Relevance, 2 is Reflection, 3. Interactivity, 4 is Tutor Support, 5 is Peer Support, 6 is Interpretation. while Q is the questions in each category. The score is the value multiplied by the likert used. Average means the score is divided by the number of respondents. For example a score of 40 divided by 10 respondents so that an average of 4.0. Table 1 is an evaluation of e-learning with 24 actual questions. The table shows that te actual average is very good (VG) consist of 6 and good $(\mathrm{G})$ consist of 24 . Table 2 is a table of COLLES method evaluation for preferred. this table with good results as much as 20 and very good as much as 4 . The conclusion can be taken from the results of the questionnaire analysis that has been filled outstudents, among others, that overall the level comfort of students in carrying out knowledge sharing using the e-learning COLLES system is enough high. this can be seen from the results of the questionnaire being in good and very good judgment.

Table 2. COLLES method evaluation for preferred

\begin{tabular}{llllllllll}
\hline No & Q & SS & S & N & TS & STS & Score & average & Inf \\
\hline 1 & A & 2 & 6 & 1 & 1 & 0 & 39 & 3.9 & $\mathrm{G}$ \\
& B & 4 & 3 & 2 & 1 & 0 & 40 & 4.0 & $\mathrm{G}$ \\
& C & 3 & 4 & 2 & 1 & 0 & 40 & 4.0 & $\mathrm{G}$ \\
& $\mathrm{D}$ & 3 & 4 & 2 & 1 & 0 & 40 & 4.0 & $\mathrm{G}$ \\
2 & A & 3 & 7 & 0 & 0 & 0 & 43 & 4.3 & $\mathrm{VG}$ \\
& $\mathrm{B}$ & 2 & 8 & 0 & 0 & 0 & 42 & 4.2 & $\mathrm{VG}$ \\
& $\mathrm{C}$ & 1 & 7 & 2 & 0 & 0 & 39 & 3.9 & $\mathrm{G}$ \\
& $\mathrm{D}$ & 2 & 6 & 2 & 0 & 0 & 40 & 4.0 & $\mathrm{G}$ \\
3 & $\mathrm{~A}$ & 4 & 3 & 3 & 0 & 0 & 41 & 4.1 & $\mathrm{G}$ \\
& $\mathrm{B}$ & 1 & 8 & 1 & 0 & 0 & 40 & 4.0 & $\mathrm{G}$ \\
& $\mathrm{C}$ & 2 & 6 & 2 & 0 & 0 & 40 & 4.0 & $\mathrm{G}$ \\
& $\mathrm{D}$ & 2 & 5 & 3 & 0 & 0 & 39 & 3.9 & $\mathrm{G}$ \\
4 & $\mathrm{~A}$ & 3 & 4 & 2 & 1 & 0 & 39 & 4.0 & $\mathrm{G}$ \\
& $\mathrm{B}$ & 1 & 7 & 1 & 1 & 0 & 38 & 4.0 & $\mathrm{G}$ \\
& $\mathrm{C}$ & 2 & 6 & 1 & 1 & 0 & 39 & 4.2 & $\mathrm{G}$ \\
& $\mathrm{D}$ & 2 & 5 & 2 & 1 & 0 & 38 & 4.0 & $\mathrm{G}$ \\
5 & $\mathrm{~A}$ & 2 & 5 & 2 & 0 & 0 & 41 & 4.1 & $\mathrm{G}$ \\
& $\mathrm{B}$ & 2 & 5 & 3 & 0 & 0 & 39 & 3.9 & $\mathrm{G}$ \\
& $\mathrm{C}$ & 2 & 5 & 3 & 0 & 0 & 39 & 3.9 & $\mathrm{G}$ \\
& $\mathrm{D}$ & 4 & 6 & 0 & 0 & 0 & 44 & 4.4 & $\mathrm{VG}$ \\
6 & $\mathrm{~A}$ & 3 & 6 & 1 & 0 & 0 & 41 & 4.1 & $\mathrm{G}$ \\
& $\mathrm{B}$ & 3 & 5 & 2 & 0 & 0 & 41 & 4.1 & $\mathrm{G}$ \\
& $\mathrm{C}$ & 4 & 5 & 0 & 1 & 0 & 42 & 4.2 & $\mathrm{G}$ \\
& $\mathrm{D}$ & 3 & 7 & 0 & 0 & 0 & 43 & 4.3 & $\mathrm{VG}$ \\
\hline
\end{tabular}


Table 3. Total overall average

\begin{tabular}{llllllll}
\hline & SS & S & N & TS & STS & Total & average \\
\hline Actual & 37 & 131 & 33 & 4 & 2 & 836 & 3.485 \\
Preferred & 56 & 133 & 37 & 9 & 0 & 1203 & 5.0125 \\
\hline
\end{tabular}

Table 3 represents the total overall average of actual and prefereed. in the table the actual results are 3.485 and prefereed is 5.0125. with these results, UNPAM e-learning is still in the good category.

\section{CONCLUSION}

Knowledge Management implementation and knowledge transfer at University ELearning have been effectively used by all faculties at UNPAM. Research tools such as COLLES can help investigate the quality of knowledge transfer in an online learning environment. Thus students are quite comfortable in sharing knowledge through distance learning. This questionnaire is carried out in 6 categories namely relevant, relative thinking, interactivity, tutor support, peer support and interpretation. the results of the questionnaire with 10 respondents through 24 questions in real time with the actual criteria and prefereed quite well. This can be seen from the results of the actual questionnaire that has the results of 6 Very Good and 18 good and the prefereed category with the results of 4 very good and the remaining 20 good. The average total results also show in good categories with 3.4 actual and 5.0 prefereed. 


\section{References}

[1] I. Y. Kazu and M. Demirkol, "Kazu, I. Y., \& Demirkol, M. (2014). Effect of Blended Learning Environment Model on High School Students' Academic Achievement. Turkish Online Journal of Educational Technology - TOJET, 13(1), 78-87. Retrieved from http://search.ebscohost.com/login.aspx?d," Turkish Online J. Educ. Technol. - TOJET, vol. 13, no. 1, pp. 78-87, 2014.

[2] M. H. Can, "An Investigation of Teacher's Use of Elearning in Science Olympiad in Russian Schools," Procedia - Soc. Behav. Sci., vol. 191, pp. 241-249, 2015, doi: 10.1016/j.sbspro.2015.04.484.

[3] H. R. Chen and H. F. Tseng, "Factors that influence acceptance of web-based elearning systems for the in-service education of junior high school teachers in Taiwan," Eval. Program Plann., vol. 35, no. 3, pp. 398-406, 2012, doi: 10.1016/j.evalprogplan.2011.11.007.

[4] M. M. Tersegno and L. Berlin, "Biopsy or Follow-Up Mammography? [2] (multiple letters)," Am. J. Roentgenol., vol. 181, no. 6, pp. 1716-1717, 2003, doi: 10.2214/ajr.181.6.1811716b.

[5] P. Nedungadi and R. Raman, "A new approach to personalization: Integrating elearning and m-learning," Educ. Technol. Res. Dev., vol. 60, no. 4, pp. 659-678, 2012, doi: 10.1007/s11423-012-9250-9.

[6] Y. Goda, M. Yamada, H. Kato, T. Matsuda, Y. Saito, and H. Miyagawa, "Procrastination and other learning behavioral types in e-learning and their relationship with learning outcomes," Learn. Individ. Differ., vol. 37, pp. 72-80, 2015, doi: 10.1016/j.lindif.2014.11.001.

[7] P. Studi, T. Industri, F. R. Industri, and U. Telkom, "PERANCANGAN MEDIA PEMBELAJARAN BERUPA E-LEARNING SOLIDWORKS UNTUK MODUL MOLDING DENGAN AJAR DI KEPROFESIAN PDE Gambar 1 Hasil Kuisioner Tingkat Kebutuhan," vol. 2, no. 1, pp. 782-790, 2015.

[8] J. Bichsel, "The state of e-learning in higher education: An eye toward growth and increased access," Proc. ASCILITE 2010, pp. 75-86, 2013, doi: http://hdl.cqu.edu.au/10018/55464.

[9] T. Brahimi and A. Sarirete, "Learning outside the classroom through MOOCs," Comput. Human Behav., vol. 51, pp. 604-609, 2015, doi: 10.1016/j.chb.2015.03.013.

[10] D. Castillo-Merino and E. Serradell-López, "An analysis of the determinants of students' performance in e-learning," Comput. Human Behav., vol. 30, pp. 476-484, 2014, doi: $10.1016 / j . c h b .2013 .06 .020$.

[11] I. Wahyudi, "Pengembangan Program Pembelajaran Fisika SMA Berbasis E-Learning dengan Schoology," J. Ilm. Pendidik. Fis. Al-Biruni, vol. 6, no. 2, p. 187, 2017, doi: 10.24042/jipfalbiruni.v6i2.1850.

[12] J. C. Wyatt and P. Taylor, "Decision Support Systems and Clinical Innovation," Get. Res. Find. into Pract. Second Ed., pp. 123-137, 2008, doi: 10.1002/9780470755891.ch11.

[13] B. Sarayreh, A. Mardawi, and R. Dmour, "Comparative Study : The Nonaka Model of Knowledge Management," Int. J. Enginineering Adv. Technol., vol. 1, no. 6, pp. 45-48, 2012.

[14] O. K. Creation, I. Nonaka, T. Knowledge, and E. Knowledge, "Nonaka' s Four Modes of Knowledge Conversion," Organization, vol. 5, pp. 14-37, 1997.

[15] P. Gottschalk, "Stages of knowledge management systems in police investigations," Knowledge-Based Syst., vol. 19, no. 6, pp. 381-387, 2006, doi: 
10.1016/j.knosys.2006.04.002.

[16] Rhem AJ, “О.Е. Баксанский Руководство процессом познания: Knowledge Management," Философия И Культура, vol. 3, nо. 3, pp. 366-381, 2013, doi: 10.7256/1999-2793.2013.03.10.

[17] S. R. Fernandez IB, Knowledge Management: System and Processes. .

[18] B. Sohrabi, I. R. Vanani, and H. Iraj, "The evolution of e-learning practices at the University of Tehran: A case study," Knowl. Manag. E-Learning, vol. 11, no. 1, pp. 20-37, 2019, doi: 10.34105/j.kmel.2019.11.002.

[19] M. Aparicio, F. Bacao, and T. Oliveira, "Grit in the path to e-learning success," Comput. Human Behav., vol. 66, pp. 388-399, 2017, doi: 10.1016/j.chb.2016.10.009.

[20] P. Allison, "A Case Study Of E-Learning initiatives in new Zeland's Secondary schools. Doctoral Dissertation," J. Chem. Inf. Model., vol. 53, no. 9, p. 261, 2011, doi: 10.1017/CBO9781107415324.004.

[21] T. T, "EVALUASI USABILITY PADA APLIKASI E-LEARNING DI JURUSAN TEKNIK INFORMATIKA UNIVERSITAS PAMULANG," vol. 11, no. 2, pp. 139-149, 2018.

[22] F. Gozali and B. Lo, "Pemanfaatan Teknologi Open Source Dalam Pengembangan Proses Belajar Jarak Jauh di Perguruan Tinggi,” J. Nas. Pendidik. Tek. Inform., vol. 1, no. 1, p. 47, 2012, doi: 10.23887/janapati.v1i1.9767.

[23] S. J. Allen IE, "Grade Change: Tracking online Education in The United States.," Retrieved from http//www.onlinelearningsurvey.com/reports/gradechange.pdf, 2014.

[24] R. L. Arief NH, "Development of Learnboost-Based E-Learning Media in Basic Competence in Implementing the Basic Gate of Logic Sequence in SMK 1 Jetis Mojokerto. Journal of Electrical Engineering Education.," Vol. 04 Number 02 577-582., 2015.

[25] W. I., "With, Development of High School Physics Learning Programs Based on ELearning Schoology.," Al-Biruni Phys. Educ. Sci. Journal., doi: 187-199: 2303-1832.

[26] S. S. Baihaqi MAW, Rosidi A, "Usability Analysis of E-Learning Applications at the Faculty of Engineering and Computer Science Unsiq Wonosobo.," J. PPKM III 159-173 $2354869 x$.

[27] P. C. Dougiamas, Martin and Taylor, "Interpretive analysis of internet based courses using the new courseware tool called Moodle," HERDSA Conf.

[28] A. Solichin, "Mengukur Tingkat Kenyamanan Penggunaan Sistem E-learning Moodle dalam Proses Knowledge Sharing : Studi Kasus di Universitas Budi Luhur," Budi Luhur Inf. Technol., vol. 6, no. 1, pp. 43-50, 2009.

[29] Sugiyono, "Quantitative and Qualitative Research Methods and R \& D," Bandung Alph. Publ. 2013. 